\title{
Aeration Process in Bioreactors as the Main Energy Consumer in a Wastewater Treatment Plant. Review of Solutions and Methods of Process Optimization
}

\author{
Jakub Drewnowski ${ }^{1, *(D)}$, Anna Remiszewska-Skwarek ${ }^{1}$, Sylwia Duda ${ }^{2}$ and \\ Grzegorz Lagód ${ }^{3}$ (D) \\ 1 Faculty of Civil and Environmental Engineering, Gdansk University of Technology, Narutowicza 11/12, \\ 80-233 Gdansk, Poland; anna.skwarek@pg.edu.pl \\ 2 Institute of Agrophysics, Polish Academy of Sciences, 20-290 Lublin, Poland; s.duda@ipan.lublin.pl \\ 3 Faculty of Environmental Engineering, Lublin University of Technology, 20-618 Lublin, Poland; \\ g.lagod@pollub.pl \\ * Correspondence: jdrewnow@pg.edu.pl; Tel.: +48-58-348-63-62; Fax: +48-58-347-24-21
}

Received: 31 March 2019; Accepted: 16 May 2019; Published: 24 May 2019

\begin{abstract}
Due to the key role of the biological decomposition process of organic compounds in wastewater treatment, a very important thing is appropriate aeration of activated sludge, because microorganisms have to be supplied with an appropriate amount of oxygen. Aeration is one of the most energy-consuming processes in the conventional activated sludge systems of wastewater treatment technology (may consume from $50 \%$ to $90 \%$ of electricity used by a plant), which makes it the most cost-generating process incurred by treatment plants. The paper presents the construction of aeration systems, their classification as well as parameters and factors that significantly affect the aeration process e.g., oxygen transfer efficiency, diffuser fouling, methods of dealing with diffuser fouling, diffuser selection. Additionally, there are briefly presented "smart control" systems in wastewater treatment and effect of application control strategy based on Supervisory Control and Data Acquisition system connected with the decrease in the energy consumption for aeration of bioreactors with activated sludge. It is noted that before the process is optimized, the system should be equipped with suitable metering devices. Only when relevant data is available, the improvements can be carried out. However, it's important, that the operator should regularly maintain good condition and high efficiency of diffusers.
\end{abstract}

Keywords: aeration process; wastewater treatment processes; activated sludge; bioreactors; nutrient removal; energy consumption

\section{Introduction}

Adjusting the municipal wastewater quality treated in the East-Central Europe to the legal regulations in the European Union pertaining to reducing the load of biogenic and toxic substances discharged to the natural environment, has caused an intensive implementation of highly efficient methods of biological and chemical treatment of wastewater, mainly with the activated sludge method [1-4]. At present, a major part of wastewater treatment plants working on mentioned area employ the systems with integrated removal of carbon, nitrogen and phosphorus compounds, in which the treatment process is carried out under aerobic-anaerobic conditions. Therefore, appropriate aeration of the activated sludge is of great importance. However, it also constitutes one of the most energy-consuming processes in the wastewater treatment technology, as is presented in Figure 1. 
The aeration process may consume from about $50 \%$ to $90 \%$ of electricity used by a treatment plant (depending on its size and the employed technological solutions), while the cost of consumed power may constitute as much as $15-49 \%$ of total costs within a plant [5-7].

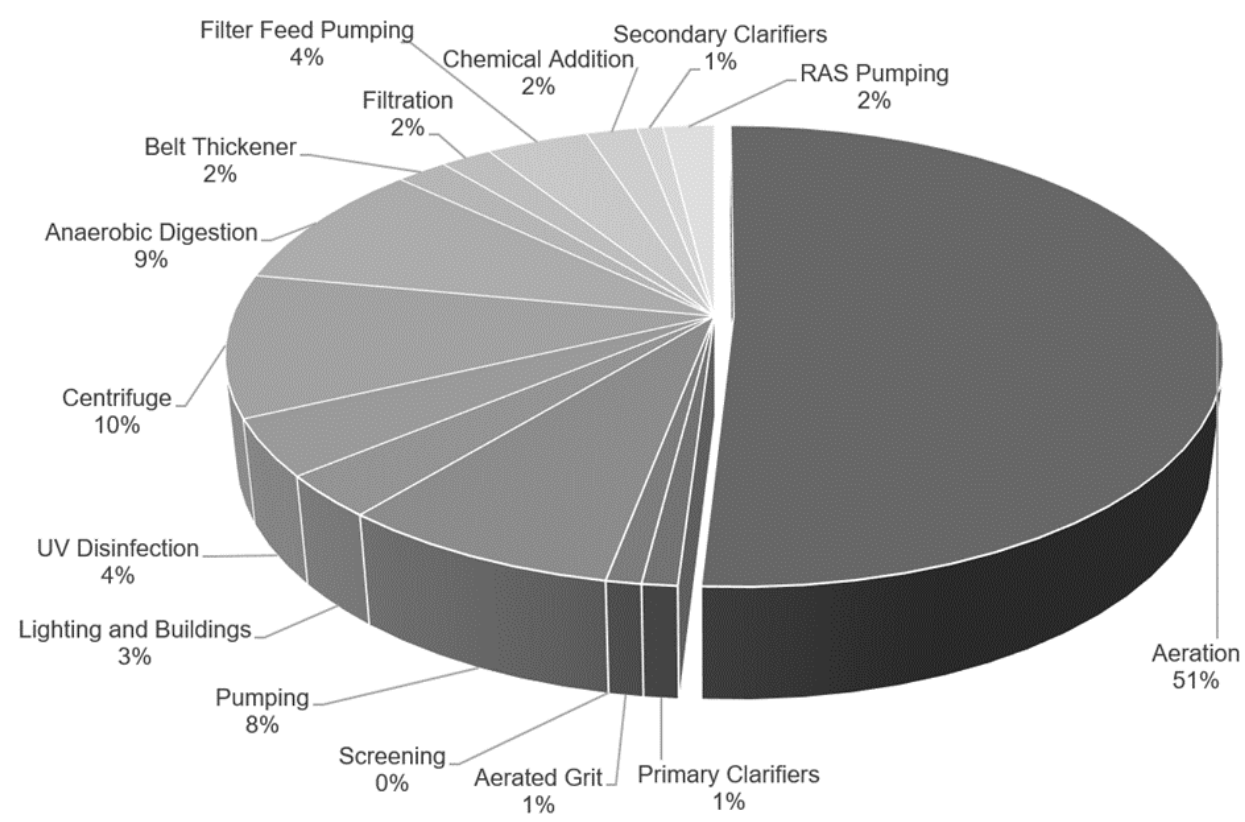

Figure 1. Estimated usage of power for 20-mgd nitrifying activated sludge facility described in [8] and data from WWTPs located in Poland.

Considering that the highly efficient wastewater treatment method has contributed to a quick increase in the cost connected with the management of ever-growing amounts of sludge, plant operators are forced to implement the optimizing solutions in order to reduce the cost of the most energy-consuming processes [9]. Under these circumstances, the use of advanced technology solutions is also highly recommended, e.g., mathematical models, computer simulations and computational hardware control allow conducting the analysis of many different technological solutions in a short time and with low investigation budget, besides carrying out various scenarios and control strategies in reality. Model complexity is increasing; the advancements of computational hardware and open source platforms for model integration support the development of new solutions and tools [10-16]. Modelling becomes an integral part of the design and operation of wastewater treatment systems in gaining knowledge on the mechanisms and operational strategies playing an important role in this optimization process [17-19].

As mentioned before, the aeration process of treated wastewater constitutes the most to the costs incurred by treatment plants. Due to the key role of the process involving biological decomposition of organic compounds, microorganisms-mainly bacteria, processing organic compounds into gaseous end products and water-have to be supplied with an appropriate amount of oxygen.

\section{Aeration Systems Construction}

At present, various types of aeration devices, which ensure optimal access to oxygen to the microorganisms in the activated sludge, are employed in biological reactors of municipal wastewater treatment plants. Surface aeration (mechanical) and diffused aeration (coarse, medium, fine-bubble) are most popular; the devices for high purity oxygen aeration are much less common [20].

\subsection{Surface Aeration}

Surface aeration, e.g., carried out with Kessener brushes or rotor aerators, were highly popular until 1990s [5,21]. At present, the surface horizontal or vertical shaft aerators, air pump systems or brush aerators are used most frequently. The blades that create turbulence on the liquid surface in 
the activated sludge method are an important element of these devices. Rotating blades, rotors or brushes are used in certain biological contact oxidation ditches. Creating a turbulent flow facilitates the aeration and finally biological processes occurring in wastewater. Currently, such solutions are rarely employed, only during the modernization of the treatment plants with shallow tanks (depth up to $3.5 \mathrm{~m}$ ) or circulation ditches. Papers published by numerous scholars indicated their high energy demand, since the related energy consumption often exceeds $0.7 \mathrm{kWh} / \mathrm{m}^{3}$ of wastewater $[5,20]$.

\subsection{Aeration by Means of Blowers}

Aeration by means of blowers is the predominant solution in practical applications (owing to the readily-available, efficient and reliable blowers); therefore, this method remains the focus of the presented work.

The air compressed in blowers is transmitted via pipes to diffusers, i.e., the elements that introduce the air to wastewater, usually located near the bottom of a biological reactor. The size of air bubbles plays a key role in this method. It was shown on numerous occasions $[5,20,22]$ that their size governs how much oxygen will transfer to wastewater, through which a bubble moves towards their surface. The smaller a bubble released from a diffuser, the slower will reach the surface and the longer it will remain in wastewater; hence, it will have more time to pass oxygen, and in greater amounts. Therefore, the usage of fine-bubble diffused aeration ( $\mathrm{d}<3 \mathrm{~mm}$ bubbles) has become standardized in municipal wastewater treatment plants. In exceptional cases, medium- and coarse-bubble diffusers are employed as well; however, they are more common in other technological processes, e.g., in aerobic sludge stabilization, sand separators, or aeration of a sewage pumping station, etc. [5,22].

The problems with optimal biological reactor aeration process largely result from a number of factors influencing its stability and high efficiency. Additionally, adapting the East-Central European treatment plants to the EU requirements in a very short period of time has, unfortunately, contributed to design errors and decisions which were not well thought out, while achieving the ecological effect for the treated wastewater was prioritized, without consideration for the operating expenses.

Literature reports and research within the industry clearly indicate that in numerous cases, optimization of the aeration systems is still necessary, while the energy-intensity of the aerobic processes enforces constant upgrading of the employed devices and methods of controlling the aeration process. Improvements in the quality and operation skill are also important for reducing the energy-intensity of the considered process [23,24].

Therefore, the paper presents the parameters and factors that significantly affect the process; investigation of these "mechanisms" should have a positive influence on the process optimization.

\section{Oxygen Transfer Efficiency}

Oxygen transfer efficiency (OTE) is one of the most important parameters in aeration systems. It indicates the amount (weight or percent) of oxygen that diffuses from $1 \mathrm{~m}^{3} \mathrm{~N}$ of air to wastewater per meters of depth of an aeration reactor. The higher the OTE, the less air should be supplied to a reactor to ensure the amount required in the process.

Oxygen transfer efficiency in fine-bubble diffusion aeration depends on several factors, including [25]:

- $\quad$ substances contained in wastewater and activated sludge;

- $\quad$ SOTE—Standard Oxygen Transfer Efficiency, e.g., [\%/m];

- concentration of dissolved oxygen $\left[\mathrm{g} \mathrm{O}_{2} / \mathrm{m}^{3}\right]$;

- depth of diffusers location [m];

- $\quad$ stream of air flowing through a diffuser $\left[\mathrm{m}^{3} /\right.$ diffuser $\left.\mathrm{h}\right]$;

- wastewater temperature;

- degree of diffuser fouling. 


\subsection{Influence of the Substances Contained in a Wastewater Mixture and Activated Sludge}

In a mathematical description of the phenomenon, the $\alpha$ and $\beta$ coefficients describe the aeration efficiency (ATV-M 209E guidelines):

$$
\begin{aligned}
& \alpha=\frac{\mathrm{k}_{\mathrm{L}} \mathrm{a}_{20}(\text { wastewater })}{\mathrm{k}_{\mathrm{L}} \mathrm{a}_{20}(\text { water })}, \\
& \beta=\frac{\mathrm{C}_{\mathrm{S}, 20}(\text { wastewater })}{\mathrm{C}_{\mathrm{S}, 20}(\text { water })},
\end{aligned}
$$

where:

$\mathrm{k}_{\mathrm{L}} \mathrm{a}_{20}$ (wastewater) - volumetric oxygen transfer coefficient at $20^{\circ} \mathrm{C}$, determined in an aerated mixture of wastewater and sludge $[1 / \mathrm{h}]$;

$\mathrm{k}_{\mathrm{L}} \mathrm{a}_{20}$ (water)—volumetric oxygen transfer coefficient at $20^{\circ} \mathrm{C}$, determined in an aerated clean water $[1 / \mathrm{h}]$;

$\mathrm{C}_{\mathrm{S}, 20}$ (wastewater) - saturation with oxygen dissolved in wastewater at $20{ }^{\circ} \mathrm{C}$, determined in an aerated mixture of wastewater and sludge $\left[\mathrm{g} \mathrm{O}_{2} / \mathrm{m}^{3}\right]$;

$\mathrm{C}_{\mathrm{S}, 20}$ (water) - saturation with oxygen dissolved in water at $20^{\circ} \mathrm{C}$, determined in an aerated clean water $\left[\mathrm{g} \mathrm{O}_{2} / \mathrm{m}^{3}\right]$.

The $\alpha$ coefficient accounts for the influence of a substance on the resistance at oxygen diffusion from air to the aerated mixture and on the surface area of mass exchange. In turn, the $\beta$ coefficient corrects the oxygen solubility, which drops when pollutants are present in the aerated mixture. However, the belief that the $\alpha$ coefficient depends solely on the composition of the aerated medium is false. The studies conducted by numerous scholars proved that other factors influencing the $\alpha$ coefficient value, exist, for instance: type of utilized aerating device or mixing conditions [26-29]. For example, the research by Holroyd and Parker indicated that while applying a fine-bubble diffuser and surface aerator in the same medium, the $\alpha$ coefficient values differ for various devices ( 0.5 and 0.8 , respectively). In the case of the surface aeration, other researchers mention even the values greater than 1 [30,31]. This phenomenon was described in 2001 [27]; it was shown that the presence of surfactants that are abundantly found in municipal wastewater (surfactants are capable of changing the surface properties of liquids in which they are dissolved) deteriorates the transfer of oxygen from air bubbles, but also significantly improves the transfer of oxygen through the wastewater surface. This means that depending on the ratio of oxygen mass diffusing to wastewater from air bubbles to the mass diffusing through wastewater surface, the total influence of surfactants will vary. In the case of coarse-bubble and mechanical aeration, the surface of aerated wastewater is more turbulent, which means that the transfer of oxygen through the surface will constitute a greater share of total transfer, contributing to higher total $\alpha$ values [25]. The second reason for higher $\alpha$ values is the way surfactants affect the transfer of oxygen from air bubbles. They reduce the transfer coefficient as a result of a greater resistance of transferred oxygen to the aerated medium. However, owing to reduced surface tension, they contribute to a reduction in the size of an air bubble, increasing the total mass exchange surface and reducing its floating rate (prolonging the contact time with wastewater). To sum up, the value of $\alpha$ depends on the size of air bubbles. While selecting the aeration system, the differentiation of the $\alpha$ value along the reactor length, which is connected with the degradation of pollutants, including surfactants, should be taken into account. For instance, the studies conducted by Fisher indicated the variability of $\alpha$ along the reactor length, from the value of 0.3 at the inlet to much higher values at the outlet, ranging from 0.7 to 1.0 [32].

The hydraulic phenomena also play an important role. It was shown [33] that both in the case of fine-bubble diffusion aeration and the use of an aerator, the oxygen transfer coefficient is a function of turbulence, dependent on the air flow rate or revolution speed of the stirrer.

The oxygen transfer coefficient values are also significantly affected by the activated sludge concentration in a reactor. Scholars proved [34] that an increase in the sludge concentrations lowers the $\alpha$ parameter, which results from an increase in viscosity. For typical sludge concentrations, 
the $\alpha$ coefficient is assumed as 0.5-0.9. In turn, they also show [35] that the transfer coefficient increases along with the sludge age, which is connected with a growing capacity of the biomass to oxidize complex compounds, including surfactants. Therefore, it was concluded that both processes occur simultaneously, and their combined effect is an individual characteristic of a given wastewater treatment plant.

Accurate determination of $\alpha$ is not an easy task and hence requires a qualified team. Assuming a mean value of 0.7 or 0.5 is often incorrect. Literature reports [35-37] provide disparate values of $\alpha$ in the case of the most frequently employed fine-bubble aeration, ranging from low ones, e.g., 0.4 , to much higher ones, i.e., $0.85-0.9$. Other studies indicate that the values for the sludge age of $12-25$ days and concentration of $2.5-5.0 \mathrm{~kg} / \mathrm{m}^{3}$, approximate the range of $0.55-0.75$ [38]. This means that if, for instance, 0.7 is assumed and the actual $\alpha$ in the system is different (lower), an error reaching several dozen percent may occur. Therefore, $\alpha$ determination should be considered if, e.g., the compliance of the supplied diffusers with the contract is being verified [25].

The $\beta$ coefficient constitutes another parameter that expresses the influence of the composition of an aerated medium on the oxygen transfer. Its value is always $\leq 1$ and for domestic wastewater, it assumes a narrow range $(0.95-0.99)[25,37]$. The values of the coefficient depend only on the composition of aerated wastewater. It is easily determined through a laboratory experiment or mathematical approximation on the basis of the following formula [26]:

$$
\beta=1.00-0.01 \frac{T D S}{1000},
$$

where:

TDS—dissolved particles $\left[\mathrm{g} / \mathrm{m}^{3}\right]$.

\subsection{Standard Oxygen Transfer Efficiency}

Standard oxygen transfer efficiency is the basic parameter characterizing the utilized diffusers (the value is also influenced by the stirring conditions). It expresses the efficiency of aeration under standard conditions $\left(20^{\circ} \mathrm{C}, 1.013 \mathrm{hPa}\right.$, clean water, i.e., $\alpha, \beta=1$, clean diffuser $\left.0 \mathrm{~g} \mathrm{O}_{2} / \mathrm{m}^{3}\right)$. This parameter is provided by a supplier. The values are usually determined under laboratory conditions; hence, the actual value of standard oxygen transfer efficiency in a reactor can be different. Therefore, an operator should verify it experimentally, preferably in a reactor filled with wastewater. Additionally, it is recommended to determine the $\alpha$ and $\beta$ coefficients.

Coarse-bubble diffusers, due to the generation of large air bubbles, are characterized by lower oxygen transfer efficiency than the fine-bubble systems [36]. However, within the same fine-bubble diffusers, the oxygen transfer efficiency is variable and ranges from 16 to $18 \mathrm{~g} \mathrm{O}_{2} / \mathrm{m}^{3} \mathrm{~N}^{*} \mathrm{~m}$ in terms of the applied air flow rate through a diffuser.

Therefore, investors should verify whether the values of the above-mentioned indicator comply with the supplier's declaration, i.e., $>20 \mathrm{~g} \mathrm{O}_{2} / \mathrm{m}^{3} \mathrm{~N}^{*} \mathrm{~m}$ at the air flow rate of several $\mathrm{m}^{3} \mathrm{~N} / \mathrm{h}$.

\subsection{Concentration of Dissolved Oxygen}

The concentration of dissolved oxygen must be sufficiently high to ensure the growth of microorganisms. Insufficient amount of oxygen disrupts the course of biological processes. Simultaneously, excessive dissolved oxygen concentration does not improve the efficiency of biological processes, merely adding to unnecessary costs incurred by pumping air.

The lack of hydrodynamic balance between the amount of oxygen in air and the amount of dissolved oxygen $\left(C_{0}\right)$ in the aerated medium drives the transfer of oxygen to water or wastewater. When there are no oxygen-consuming processes, it diffuses from the air to the aerated medium long enough to achieve saturation concentration $\left(C_{S}\right)$. Saturation concentration is a function of partial pressure (partial pressure of a single gas in a mixture) of oxygen in the supplied air and Henry's constant, the value of which depends on, i.a. temperature. The higher the partial pressure, the faster 
the oxygen transfer; it increases along with the absolute pressure of the gas and the percentage share of oxygen in a gas. Therefore, while aerating reactors with pure oxygen, deeper reactors are used than when the aeration process is carried out with alternative systems. The influence of dissolved oxygen is modeled with a driving module $\left(\mathrm{C}_{S}-\mathrm{C}_{0}\right) / \mathrm{C}_{\mathrm{S}}$, described in ATV-M 209P in greater detail.

In terms of control, the operational practice of the majority of wastewater treatment plants still involves simple dissolved oxygen control algorithms based on rules or PI regulators with fixed settings. Due to the complexity of the control issue (non-linear, non-stationary) and different operation locations, they are inadequate. Variable oxygen demand, and thus the amount of air supplied by the aerating system, is the main cause. These variations depend on the different degree of wastewater pollution, for which the desired dissolved oxygen levels should be determined [39].

\subsection{Depth of Diffuser Arrangement}

The deeper the reactor, the longer the diffusion time of oxygen from air bubbles to the aerated medium, which increases the total oxygen transfer as well. However, greater reactor depth raises the investment costs and blower compression.

\subsection{Air Flow Rate through a Diffuser}

As the air flow rate increases, the oxygen transfer efficiency drops, which is connected with the coalescence of bubbles into larger agglomeration resulting from a growing number of produced bubbles and their more frequent collisions. Therefore, while preparing the specification for ordering diffusers, an investor should precisely determine the range of air flow at which the required standard oxygen transfer efficiency can be achieved. Taking into account the above-mentioned relation, maintaining excessive oxygen concentration in a reactor, resulting from too high flow rate, often leads to a decrease in the efficiency connected with superfluous air flow rate through diffusers. As a consequence, an operator can expect unnecessary system over-oxidation and generation of substantial financial losses, reaching up to several dozen percent of the aeration budget [25].

\subsection{Wastewater Temperature}

On the one hand, the oxygen solubility drops as the temperature increases, e.g., $\left(10{ }^{\circ} \mathrm{C}: 11.3 \mathrm{~g}\right.$ $\mathrm{O}_{2} / \mathrm{m}^{3}, 25^{\circ} \mathrm{C}: 8.3 \mathrm{~g} \mathrm{O}_{2} / \mathrm{m}^{3}$ ), while on the other hand, it raises the diffusion rate. However, when both effects are combined, the influence on the oxygen transfer rate is virtually unnoticeable (literature states that the influence of various temperatures on the differences in oxygen transfer value does not exceed several percent [25]). In addition, the wastewater temperature also influences the oscillation intensity at which air bubbles float up. However, due to the difficulties in mathematical description and insignificant influence, these factors are not taken into account in the equations determining the oxygen transfer. The mathematical description of the relation between oxygen transfer efficiency and the factors that influence it was presented in detail in ATV-M 209P.

\subsection{Diffuser Fouling}

The diffuser fouling phenomenon reduces the oxygen transfer efficiency and increases the pressure losses in the network. As a result, the energy consumption of the aeration process is increased and a negative impact on the stability of the wastewater treatment process is exerted. Additionally, it accelerates the material degradation (of membranes), which contributes to their more frequent replacement. Fouling may occur as a result of the agents contained in wastewater but may also be induced by the supplied air. The list of factors that negatively affect diffusers devised by EPA is presented below [40]:

Factors originating from wastewater:

- fibrous substances;

- organic and inorganic substances infiltrating into diffuser pores as a result of insufficient air flow;

- oils, greases and fats; 
- precipitated substances, e.g., iron compounds, carbonates;

- biofilm;

- organic and inorganic substances trapped in the biofilm growing on diffuser material.

Factors originating from the air supplied to diffusers:

- particulate matter from a non-purified or inappropriately purified air;

- $\quad$ oils leaks from blowers;

- corrosion and residues from corroding pipes supplied compressed air;

- pollutants contained in wastewater infiltrating to the pipe with compressed air via damaged diffusers or cracked pipes.

\subsubsection{Types of Diffuser Fouling}

Three types of diffuser fouling are distinguished - mineral, biological and biological with high share of mineral substances [40]. Mineral fouling (I type), mainly occurs in the form of calcium carbonate that precipitates in diffuser pores at the contact point between gaseous phase and wastewater; high air temperature results in evaporation of wastewater and precipitation of mineral substances; the process is aggravated by $\mathrm{CO}_{2}$ resulting from the diffusion of wastewater to air bubbles, wherein $\mathrm{pH}$ is increased and the solubility of $\mathrm{CaCO}_{3}$ is reduced. The type I fouling process occurs faster in the pores characterized by greater diameter, initially improving the even outflow of air from diffusers and slightly increasing the oxygen transfer efficiency [40]. However, the precipitating minerals eventually block some of the diffuser pores and contribute to pressure losses which, unfortunately, raise the energy-demand of the system and leads to financial losses [25]. Internal mineral fouling usually results from the breaks in blower operation. Halting the airflow causes penetration of wastewater inside the diffusers. The resumed flow of warm air leads to a sudden evaporation and precipitation of mineral substances. The literature describes extreme cases in which high blower failure rate and the residue layer formed inside diffusers completely blocked the flow of air through a diffuser [6]. Biological fouling (II type) appear in the form of loose biofilm on the diffuser surface. The resultant free spaces lead to the formation of bubbles with greater sizes, which negatively impacts the oxygen transfer efficiency. This type of fouling has no significant influence on the pressure losses. Last type (III type) occurs as biological fouling with high share of mineral substances which block the external parts of a diffuser, reducing the oxygen transfer efficiency and pressure losses. The mechanisms of type II or III biological fouling are not fully known.

\subsubsection{Effects of Diffuser Fouling}

Diffuser fouling occurs in all types of diffusers, regardless of the producer and the materials they are made of. This phenomenon increases the pressure losses and reduces the oxygen transfer efficiency. The literature data presents the cases in which the pressure losses increased by over $500 \mathrm{~cm} \mathrm{H}_{2} \mathrm{O}$ (which seems unrealistically high), and a drop-in oxygen transfer efficiency by several dozen percent [41,42]. As mentioned before, diffuser fouling may radically increase the costs of the aeration process, or even worse-prevent maintaining the required oxygen concentration in bioreactors.

Biological fouling may cause irreversible changes in the material structure of a diffuser, e.g., as a result of the biofilm bacteria penetrating the membrane (type II fouling), caused by the application of additives (e.g., softening or elasticity increasing agents) in the manufacturing process of diffusers, which then serve as a source of nutrients. As a consequence, membrane cracking and elasticity reduction occur, eventually leading to the need to replace the damaged diffuser and incurring the related costs [43-46]. However, sometimes a situation where degradation improves the oxygen transfer efficiency may occur. In such case, reduced membrane elasticity will limit its opening, thus lowering the size of formed bubbles below the established value [35]. Unfortunately, such situation leads to greater pressure losses and the risk of membrane cracking.

In the case of the fouling process of ceramic diffusers, its negative effect can be reversed (through regeneration) and restore the parameters nearly to the initial level [42]. 


\subsubsection{Rate of Fouling and Diagnosing the Diffuser Condition}

The rate of the fouling process may vary greatly. There were cases in which rapid reduction of oxygen transfer efficiency, reaching $7 \%$ per month, was observed-leading to a $50 \%$ aeration efficiency decrease within 7 months from the system launch [40]. In another installation, a $25 \%$ efficiency decrease was noted following 18 months of operation [47]. Nevertheless, literature mentions the cases in which a $50 \%$ efficiency reduction of the aeration process occurred after 20 years of incessant system operation [40].

The occurrence of pressure loss changes in diffusers is also highly diversified; they may already occur several weeks after the beginning of operation [44], or virtually no changes may be observed throughout a year [48].

The rate of the diffuser fouling process and its consequences are an individual and often unpredictable property of every wastewater treatment plant [43]. The simplest method of evaluating their condition involves gathering and analyzing the operational data. In the case of a significant increase in pressure losses (mean), by simply analyzing the readout of pressure meter installed on the central main, it is possible to diagnose the problem. A more difficult situation occurs when the pressure loses are uneven; in such case, an operator can remain unaware of the issue for a long time. In the event of uneven oxygen supply to particular aeration sections, field observations and pressure loss measurement in particular aeration sections (performed using a portable pressure meter) are essential. Local measurements should be carried out in every larger wastewater treatment plant.

Diagnosing the diffuser condition in terms of oxygen transfer efficiency is much more difficult. The oxygen transfer efficiency can be calculated on the basis of operational data by means of comprehensive investigations pertaining to COD and nitrogen streams (flowing into and out of the aerobic chambers) and air flow rate (preferably using the data collected over at least a year). Unfortunately, it is rarely carried out due to the insufficient amount of available data, e.g., COD analyses for waste sludge are seldom performed [43]. Another option consists in removing diffusers from the reactor and testing them under laboratory conditions. Such an approach additionally identifies other fouling effects, including membrane degradation or uneven air outflow. Unfortunately, it is usually impossible or difficult (diffusers are fixed on the bottom of reactors). The best solution is to perform measurements on an operating reactor using the off-gas method, which enables to determine the fouling effect in a credible and problem-free way (the method was thoroughly described in ATV-M 209E) [43].

\subsubsection{Methods of Dealing with Diffuser Fouling}

The most popular methods of combating the fouling process can be divided into two groups: the ones that require emptying the reactor and the ones that do not. The "non-invasive" methods include addition of formic acid to the air supplying diffusers and periodic (momentary) increasing the air flow rate. Adding formic acid only enables to control the pressure losses of diffusers (limited effect on external fouling), whereas increasing the air flow rate results in the detachment of loose external biofilm fragments. Hence, this method theoretically serves to maintain the oxygen transfer efficiency at a high level.

Both methods should be used regularly (on the basis of the authors' own observations: it is recommended to cleanse the aeration zone every 1-2 months, while the formic acid addition should be performed at least twice a year) to facilitate maintaining high diffuser efficiency. Irregularity and inconsistency will result in low efficiency of both methods.

The "invasive" methods, i.e., requiring emptying of a reactor are much more efficient, but also labor-intensive and costly. Some of them require disassembly of diffusers, while other cannot be employed with all diffuser types (e.g., membrane diffusers).

The most important methods that require emptying reactors include:

- high pressure washing;

- $\quad$ pouring with hydrochloric acid;

- $\quad$ submerging in hydrochloric acid (disassembly required);

- $\quad$ firing (disassembly required); 
- $\quad$ sanding (disassembly required).

Out of the aforementioned methods of dealing with fouling, high pressure washing of diffusers-which enables to remove external fouling - is the most popular. This method does not require specialized equipment, is safe and highly efficient. Other methods are not recommended as they necessitate the use of advanced equipment or the use of a dangerous acid, while also generating high costs or increasing the risk of accidents.

\subsubsection{Diffuser Selection}

While considering the selection of fine-bubble aeration system, an operator should bear in mind that the choice is key to ensuring optimal process conditions for the aerobic activated sludge organisms [5,49].

The selection of commercially available aeration devices is not a simple task, because of the multitude of different versions (see Table 1). Usually, diffusers are installed at the bottom of reactors to minimize the occurrence of dead zones in a tank. Unfortunately, diffusers are usually fixed permanently; therefore, complete emptying of a reactor is required in case of a malfunction and a subsequent filling and start-up procedure. An alternative method involves hiring a diver (very costly approach) who works under difficult conditions of virtually zero visibility. Therefore, at the design stage, an operator should consider selecting such diffusers that will enable removal of individual system elements above the wastewater table (mainly pipe diffusers).

At present, pipe diffusers constitute one of the most commonly employed types of fine-bubble diffusers. It is simply a special pipe covered with a membrane, with appropriately cut holes or crevices. Individual diffusers are available in various lengths $(0.5$ to $1 \mathrm{~m})$ and are attached with sealed joints to steel or plastic profiles, i.e., support frames. The membrane material is selected depending on the composition of aerated wastewater. The EPDM (ethylene propylene diene monomer) membranes are manufactured out of a mechanically and chemically resistant rubber. Sufficient mechanical strength is necessary due to the variable conditions of the aeration process and/or its cyclic nature. In the course of air inflow, the membrane is elongated and the orifices close or open depending on the amount of flowing air. When the supply of air is cut, the membrane orifices close preventing the infiltration of wastewater into aeration system. There are numerous EPDM mixtures, which are characterized by diverse properties depending on their composition. Older generations of EPDM contained a lot of oxidizing plasticizers, which accelerated the ageing process or even resulted in cracking of membranes. The membranes for wastewater other than domestic can be made of, e.g., silicone (high chemical strength) or polyurethane (highly durable, but characterized by increased resistance), covered with a Teflon layer (smooth surface prevents fouling). If constant aeration is recommended and there is no risk that the supply of compressed air will cease, it is worth considering the application of which are more expensive ceramic diffusers. They consist of a porous material which is a mixture of naturally round quartz pebbles and synthetic resin. Although the risk of blocking increases during a pause in aeration, if properly utilized, they are characterized by longer lifespan in relation to membrane diffusers and lower pressure losses, which lowers the consumption of energy spent for wastewater aeration and reduces the operational costs of a wastewater treatment plant [5].

Other systems are based on disc or plate diffusers. They are screwed directly on the threaded tips on the support frame, through which the air is supplied centrally between the plastic diffuser frame and a diaphragm, creating an air cushion. Diaphragm elongation opens the orifices distributed evenly over its entire surface and the air infiltrates into wastewater in the form of fine bubbles. When the airflow is cut, the diaphragm returns to its initial position and the orifices close. Similarly, as in the pipe diffusers described above, the disc membranes are also available in many materials and in a ceramic version. Due to their design and installation method, only the wastewater above them is aerated. In practice, this removes $20-30 \mathrm{~cm}$ of reactor depth from the active volume. Pipe diffusers are capable of aerating the wastewater around them, which slightly improves the mixing of wastewater directly above the bottom of the tank. The failure-free service life of diffusers is typically determined by manufacturers 
as $5-10$ years (provided that their operation is carried out according to the recommendations). It is obvious that employing the available knowledge and best engineering practice by an operator will additionally have a beneficial effect on the technical condition of the aeration system.

Table 1. Comparison of aeration methods with typical performance data [50-54].

\begin{tabular}{|c|c|c|c|c|}
\hline Aeration Device & $\begin{array}{l}\text { Oxygen Transfer } \\
\text { Rate, } \mathrm{kgO}_{2} / \mathrm{kWh}\end{array}$ & Application & Advantages & Disadvantages \\
\hline $\begin{array}{l}\text { Fine bubble } \\
\text { diffusers }\end{array}$ & $2.0-2.5$ & $\begin{array}{l}\text { It is a standard solution } \\
\text { used in wastewater } \\
\text { treatment plants }\end{array}$ & $\begin{array}{l}\text { Small bubbles dissolve better } \\
\text { in the wastewater, which gives } \\
\text { a better aeration efficiency and } \\
\text { allows for savings by reducing } \\
\text { energy consumption. } \\
\text { It does not cause a mechanical } \\
\text { disruption of the flocks.Air } \\
\text { bubbles propagate evenly. } \\
\text { Result is lower volatile organic } \\
\text { compound emissions than } \\
\text { nonporous diffusers or } \\
\text { mechanical aeration devices. }\end{array}$ & $\begin{array}{l}\text { Fine pore diffusers are } \\
\text { susceptible to biological or } \\
\text { chemical fouling, which may } \\
\text { weaken transfer efficiency and } \\
\text { generate high head loss, as a } \\
\text { result, they require repetitive } \\
\text { cleaning. } \\
\text { Diffusers are subject to fouling } \\
\text { and scaling, resulting in loss in } \\
\text { transfer efficiency as biofilms } \\
\text { form and change material } \\
\text { properties producing larger } \\
\text { bubbles, hindering mass } \\
\text { transfer and contributing to } \\
\text { increased costs of energy. }\end{array}$ \\
\hline $\begin{array}{l}\text { Vertical shaft } \\
\text { aerators }\end{array}$ & up to 2.0 & $\begin{array}{l}\text { Used in vertical shaft } \\
\text { bioreactors }\end{array}$ & $\begin{array}{l}\text { Low operating and } \\
\text { maintenance costs. } \\
\text { High oxygen transfer } \\
\text { efficiency. } \\
\text { A fixed or floating set of } \\
\text { devices (Fully accessible } \\
\text { without the need of draining } \\
\text { the tanks). }\end{array}$ & $\begin{array}{l}\text { It can cause a mechanical } \\
\text { disruption of the flocks. } \\
\text { To obtain optimum peripheral } \\
\text { velocity, highest rotation } \\
\text { speed and smallest impeller } \\
\text { diameter ratio should be } \\
\text { applied. }\end{array}$ \\
\hline $\begin{array}{l}\text { Horizontal shaft } \\
\text { aerators }\end{array}$ & up to 2.0 & $\begin{array}{l}\text { They are especially } \\
\text { preferred in ditch type } \\
\text { aeration basins, due to } \\
\text { their effective mixing and } \\
\text { high oxygen transfer } \\
\text { efficiency in shallow, wide } \\
\text { channels. As the rotor } \\
\text { turns, a vertical movement } \\
\text { of water is created and } \\
\text { water is aerated. }\end{array}$ & $\begin{array}{l}\text { It works well in chambers with } \\
\text { a high concentration of solids. } \\
\text { Fully accessible without the } \\
\text { need of draining the tanks. } \\
\text { Simple construction, easy, } \\
\text { to build, maintain and repair }\end{array}$ & $\begin{array}{l}\text { Limited Mixing } \\
\text { Performance-A surface } \\
\text { aerator can really only mix the } \\
\text { water in its immediate vicinity. } \\
\text { The combination of splashing } \\
\text { water, and being exposed to } \\
\text { freezing rain and snow, makes } \\
\text { these motors prone to failure } \\
\text { in cold weather }\end{array}$ \\
\hline
\end{tabular}

\section{4. "Smart Control" in Wastewater Treatment}

In accordance with the most recent global trends, mathematical modeling becomes an indispensable element of design as well as operation of wastewater treatment plants [55]. Application of mathematical models enables to examine numerous technological solutions and simulate the events that are unusual for typical operating conditions of an actual system in a relatively short period of time and at low cost [56].

Due to a constant reduction of prices, implementation of state-of-the-art process control algorithms in full-scale wastewater treatment plants becomes increasingly possible. It should be emphasized that the employing of appropriate mathematical models enables the application of only some of process parameters transducers, the remaining variables can be calculated, usually in real-time.

In order to design an advanced system controlling the driving systems of bioreactor chamber aeration, it is necessary to select an appropriate model describing the phenomena occurring in the wastewater treatment process [56-60].

The first comprehensive mathematical model of the activated sludge processes, called ASM 1 (Activated Sludge Model No. 1), accounting for the removal of carbon compounds and transformations of nitrogen compounds was already devised in the 1980s [61]. ASM 2, which additionally included 
the biological and chemical phosphorus removal, was introduced in subsequent years and comprised 19 components (9 soluble and 10 insoluble ones) [62].

Further studies on the phosphorus-accumulating bacteria and the observations made by various scholars proved that some of them are capable of utilizing the nutrients stored inside cells for the denitrification process and that these organisms can grow under anoxic conditions, in addition to aerobic ones. These observations were also reflected in the kinetic model, thus increasing the number of processes to 21. Hence, ASM 2d is an updated version of ASM 2 in terms of the phosphorus-accumulating bacteria [56,62-64]. Subsequent models based on modified ASM [56] were devised, e.g., asmVienna [65] or BIO-P module [66]. Apart from the ASM models, which are based on the COD balance, there are models relying on the BOD balance, e.g., ASAL models $[67,68]$. The models that describe the metabolism of the organisms participating in pollution decomposition constitute a separate category and include, i.a. TUDP models $[69,70]$. The most recent trend in modeling of wastewater treatment processes involves incorporating the entire system, rather than its selected fragment.

Only a properly selected model enables to determine the optimal strategy for controlling the biological-chemical process in a given wastewater treatment plant. However, practical implementation of the controlling system requires installing suitable sensors that provide the data on the current process parameters [71].

Unfortunately, obsolete controlling systems based on a constant oxygen value in the aerobic chambers $\left(1-3 \mathrm{~g} / \mathrm{m}^{3}\right)$ and constant recirculation values of $50 \div 100 \%$ influent wastewater are still used in many wastewater treatment plants [57-60]. Such a simple system does not account for the variability of parameters characterizing the influent wastewater (daily, annual) or the temperature at which the biological-chemical processes occur. This means that the driving systems controlling the process operate continuously and independently from the situation in the bioreactor and secondary settling tank. The possible emergencies (e.g., suspension in the outlet) are only detected by the staff and remedied by taking additional actions. These systems are highly inefficient due to the amount of consumed energy and the quality of discharged treated wastewater [70].

The literature describes a number of strategies that can be employed in wastewater treatment plants $[56,57,61,72-74]$ :

- the simplest strategies do not use the feedback signals and are only based on supplying appropriate amount of air to the object;

- more advanced strategies employ the feedback from the oxygen level in nitrification zones;

- the most recent strategies involve the feedback from the remaining variables (ammonia nitrogen, total nitrogen) and use it to adjust the optimal level of oxygen concentration (and recirculation) in aerobic.

In large plants, chemical compounds are additionally introduced as an external source of carbon to improve the quality of treated wastewater. They contribute to the further improvement of the process and are accounted for in the controlling algorithms.

The source literature states that model predictive control (MPC) is considered one of the most advanced solutions [61], enabling to select optimal control sequence in a given time horizon. This ensures optimal process control and minimizes the costs of operating a wastewater treatment plant. The disadvantages of MPC include the complex calculating algorithm as well as the requirement of data on condition variables and process disruptions [62].

Advanced aeration control strategies can be also based onto on-line measurements of nitrogen compounds [75]. Since more reliable ammonium $\left(\mathrm{NH}_{4}{ }^{+}\right)$and nitrate/nitrite (NOx) sensors have appeared on the market, new opportunities became available. As far as the ABAC (Ammonia-Based Aeration Control) system is concerned, the DO concentration changes are controlled by measuring the $\mathrm{NH}_{4}{ }^{+}$concentration. In turn, the AVN system (Ammonia vs. Nitrate/Nitrite) involves measuring $\mathrm{NH}_{4}{ }^{+}$as well as NOx concentrations [75-78]. 
The ABAC system involves two types of control strategies, determined by the placement of $\mathrm{NH}_{4}{ }^{+}$ sensors in the biological reactor: the feedback control is employed for the measurements taken in the nitrification compartment outflow, whereas the feedforward-in the nitrification compartment inflow. Controlling aeration by means of the ABAC system enables substantial savings in electricity consumption (approximately 10-20\%), as well as improves the denitrification process by reducing alkalinity and consumption of organic carbon [77]. Although the feedforward control is more complex, it enables to achieve the required wastewater quality by consuming less energy.

Originally, the AVN system was devised to remove nitrifying bacteria (NOB) oxidizing nitrites to nitrates in second stage of the systems with a shortened nitrification path [76]. The AVC system, apart from shortening the nitrification path, improves the nitrogen removal when controlling the conventional nitrification-denitrification process. The nitrate load for denitrification is adjusted by setting the $\mathrm{NH}_{4}{ }^{+}$and $\mathrm{NO}_{x}$ concentrations in the outflow.

Mentioned above smart process control systems are the future of the wastewater treatment plant (WWTPs) exploitation strategy. They involve a simulation model implemented in computer software with an appropriate algorithm used for controlling biochemical processes on the basis of on-line measurements obtained from the set locations in the bioreactor. At present, the computer models of wastewater treatment processes are utilized as a supplementary tool and aid in selecting different types of technologies and optimal solutions. Regardless of the investor's decision on how advanced the control system should be, implementation of smart control to the treatment system results in greater flexibility of blower operation time, elimination of over-oxidation periods, as well as higher stability of the treatment system, which contributes to substantial savings related to lower power consumption.

In terms of energy intensity of the aeration processes, it is also worth mentioning the methods aiding the decision-making process related to the energy aspects within a wastewater treatment plant [79]:

- Economic efficiency analysis (EEA) -EEA involves the analysis of capital and operating costs, as well as the economic benefit characterizing WWTPs. It focuses on decreasing the operating costs using advanced systems of control, and improving the energy recovery, thus increasing the economic benefit [80-82];

- Carbon footprint analysis (CFA) - CFA is employed for measuring the total amount of greenhouse gases produced during the operation of wastewater treatment plant. The carbon footprint in WWTPs can be mitigated by decreasing the energy consumption through on-site energy recovery and improving the efficiency of aeration [83-88];

- Life cycle assessment (LCA) - LCA constitutes a standardized procedure which is employed for examining the environmental aspects characterizing wastewater treatment plants. This approach was adopted in a few studies in order to investigate the energy-related issues, including the production of biogas as well as AD [89-91];

- Data envelopment analysis (DEA) -DEA is commonly used to evaluate the eco-efficiency, frequently when the available data is limited. The eco-efficiency of a treatment plant is determined by integrating such factors as energy consumption, economic cost, removal of pollutants as well as contribution to the global warming effect [24,92-95];

- Plant-wide modeling - the performance of wastewater treatment plant can be predicted using simulation tools and analysis of the data pertaining to energy consumption as well as the influent and effluent quality. This approach is also viable when one wishes to compare various strategies of achieving energy neutral condition. The performance of wastewater treatment plants can also be evaluated using multi-objective approach with dynamic process model involving LCA, detailed energy models, GHG and operational costs [10-16]. 


\section{Modelling, Design, and Functions of the Control System on the Example of "Dębogórze" WWTP}

Energy consumption is crucial in determining the WWTP operating costs. The main objective of the practical application was to model different aeration strategies in order to improve biochemical processes and energy balance using newly developed controllers in GPS-x ver. 6.5.1-mathematical modeling and computer simulation platform [96]. The mathematical modeling and computer simulations were carried out based on the ASM2d model, according to Henze et al. [64] In order to perform accurate calibration, the data sets from both full-scale WWTP and laboratory batch tests were used from previous study [18]. The stoichiometric and kinetic parameters were determined by means of numerical optimization using the Nelder-Mead simplex method [97]. Briefly, the data sets obtained from the full-scale "Debogórze" WWTP in Gdynia performed by Drewnowski and coworkers $[18,19]$ were used for steady-state simulations in the software GPS-x. The respirometric batch tests (OUR and corresponding COD consumption for estimating fractionation) were carried out and the OUR, biodegradable substrate monitoring and the conditions of activated sludge were also determined. The control processes of variable variants for aeration zone were tested under the steady-state operational conditions at the studied WWTP. Once calibrated and validated, the model and the data collected previously throughout different seasons were used to evaluate the performance of "Debogorze" WWTP as well as to validate the COD fractionation and modeling approach for appropriate optimization [19].

Moreover, computer simulations were also used to estimate ON/OFF controller for dissolved oxygen variable, ON/OFF controller for the ammonium variable, PID controller for the dissolved oxygen variable and ON/OFF for the variable ammonium as well as more complex systems, e.g., ammonia-based aeration control (ABAC). In the study, modeling aeration control strategies for low energy process control in WWTP was based on a compilation of $\mathrm{NH}_{4}-\mathrm{N}$ level control as opposed to the more commonly seen aeration intensity control with DO set-points. Figure 2 presents the sample results of $96-\mathrm{h}$ measurement campaign under summer conditions in the full-scale modified Johannesburg (JHB) bioreactor in aerobic zone and model predictions at the studied plant as well as the newly developed application in GPS-X of the PID and ON/OFF controller for WWTP modelling as a tool to upgrade and optimize the plant operation.

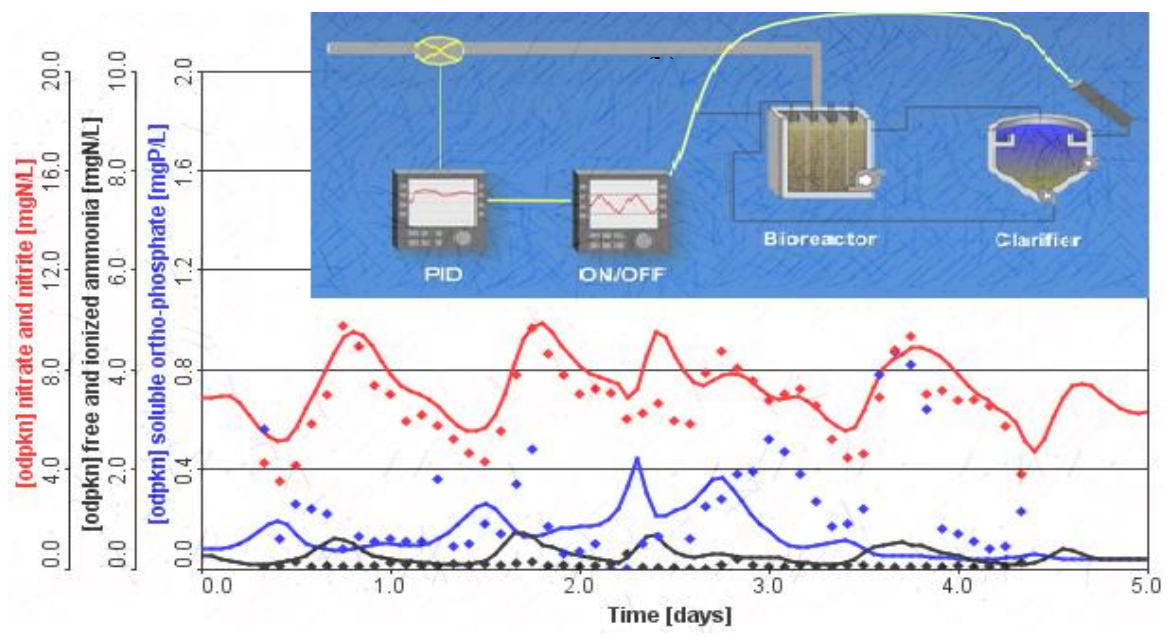

Figure 2. Sample results of estimated power usage in GPS-x simulation platform and model predictions at studied WWTP [based on a previous study conducted by Drewnowski and co-authors $[18,19]$.

After several expansions and modernizations, the treatment line consisted of four parallel bioreactors running in the JHB process. The new biological reactors were designed with simultaneous nitrification-denitrification and biological phosphorus removal in a carrousel system. The total volume of a single bioreactor line is $12,000 \mathrm{~m}^{3}$, which is the volume corresponding to the aerobic zone of about $4625 \mathrm{~m}^{3}$. During the GPS-x computer simulation, the changes in the concentration of nitrogen and phosphorus in biological bioreactors and in the effluent from the studied "Dębogórze" WWTP were 
below limits $(\mathrm{P}=1 \mathrm{mg} / \mathrm{L}, \mathrm{N}=10 \mathrm{mg} / \mathrm{L})$. The sample results of model predictions in JHB bioreactor are presented in Figure 2. A schematic layout of the bioreactor, including the information about the compartment volumes and on-line instruments locations, was presented in a previous study conducted by Drewnowski and co-authors $[18,19]$.

Process optimization was performed based on "human expert" biological system physiology supported by a "conventional" study as well as mathematical modeling and computer simulations in order to implement the next level of system operations that are required to minimize the use of energy in the existing facilities. Finally, supervisory Control and Data Acquisition (SCADA) system was implemented in the "Debogórze" WWTP, in which the process data are transmitted from the controllers via optical fiber computer network. The industrial computer network involves the entire AKPiA system comprising 21 controllers and 4 SCADA workstations. Each controller provides control over a separate area with the corresponding technological devices. The controllers receive the signals that enable automatic control over the actuators in accordance with the required algorithm.

The controller tasks are as follows:

- implementation of an automatic process control algorithm in the allocated area,

- remote control via computer in the Central Dispatcher (manual and automatic),

- transmitting the information on technological parameters and device condition via the computer network to the Central Dispatche.

Each controller is equipped with graphical user interface that enables monitoring the technological parameters and state of technological devices in the monitored area, changing the settings of devices, local control and diagnosing damages.

The automatization and control system for the aeration of bioreactors involves, i.a.:

- controlling the correctness of the nitrification process on the basis of readouts from the ammonia nitrogen measurement devices installed at the outlets from particular reactor blocks;

- automatic regulation of the aeration level depending on the concentration of ammonia nitrogen at the reactor outlets-the control system sets the oxygen concentration which should be maintained in particular aerobic zones of reactors;

- probes ensure automatic regulation of the correct oxygen level in particular aerobic zones-the amount of air supplied to particular zones is controlled with electric throttle valve, while the control system ensures the high efficiency of blowers.

Figure 3 presents the control over the set oxygen value, starting with the ammonia nitrogen concentration at the reactor outlet. The red line corresponds to the ammonia nitrogen concentration, the blue line-the set oxygen concentration in Zone I (nitrification), the green line-the set oxygen concentration in Zones II and III (simultaneous denitrification).

Figure 4 shows the variability of the set oxygen level and the blower efficiency depending on the ammonia nitrogen concentration. This graph presents the blower operation with varying efficiency (blue line), depending on the set oxygen level (green line) which is controlled by the system on the basis of the ammonia nitrogen concentration (red line) over the period of $48 \mathrm{~h}$.

The control strategy adopted in described wastewater treatment plant enables the blowers to operate with the efficiency adjusted to the actual process requirements and protects against the unnecessary over-oxidation during the period of lower oxygen demand. Additionally, this contributes to higher efficiency of denitrification and lower oxygen demand. The on-line data sets (e.g., $\mathrm{NH}_{4}-\mathrm{N}$, $\mathrm{NH}_{3}-\mathrm{N}, \mathrm{pH}, \mathrm{ORP}$ ) were collected in order to reduce the uncertainty around the main processes. These data were taken on-line from each of the 10 processes lines of "Debogorze" WWTP by the implemented computer system: these analyses were carried out by using an automatic analyzer provided by Hach Lange GmbH: 
1. $\mathrm{NH}_{4}-\mathrm{N} / \mathrm{NH}_{3}-\mathrm{N}$ probe, AMTAX/NITRATAX (reagent analyzers) together with the probe filter, type: LXG421/LXG417,

2. DO concentration in each of the three oxygen sections at each bioreactor was measured on-line by using a luminescent dissolved oxygen probe,

3. $\mathrm{pH}$ and ORP were on-line measured by using $\mathrm{pH}$ and ORP probes supplied by Hach-Lange.

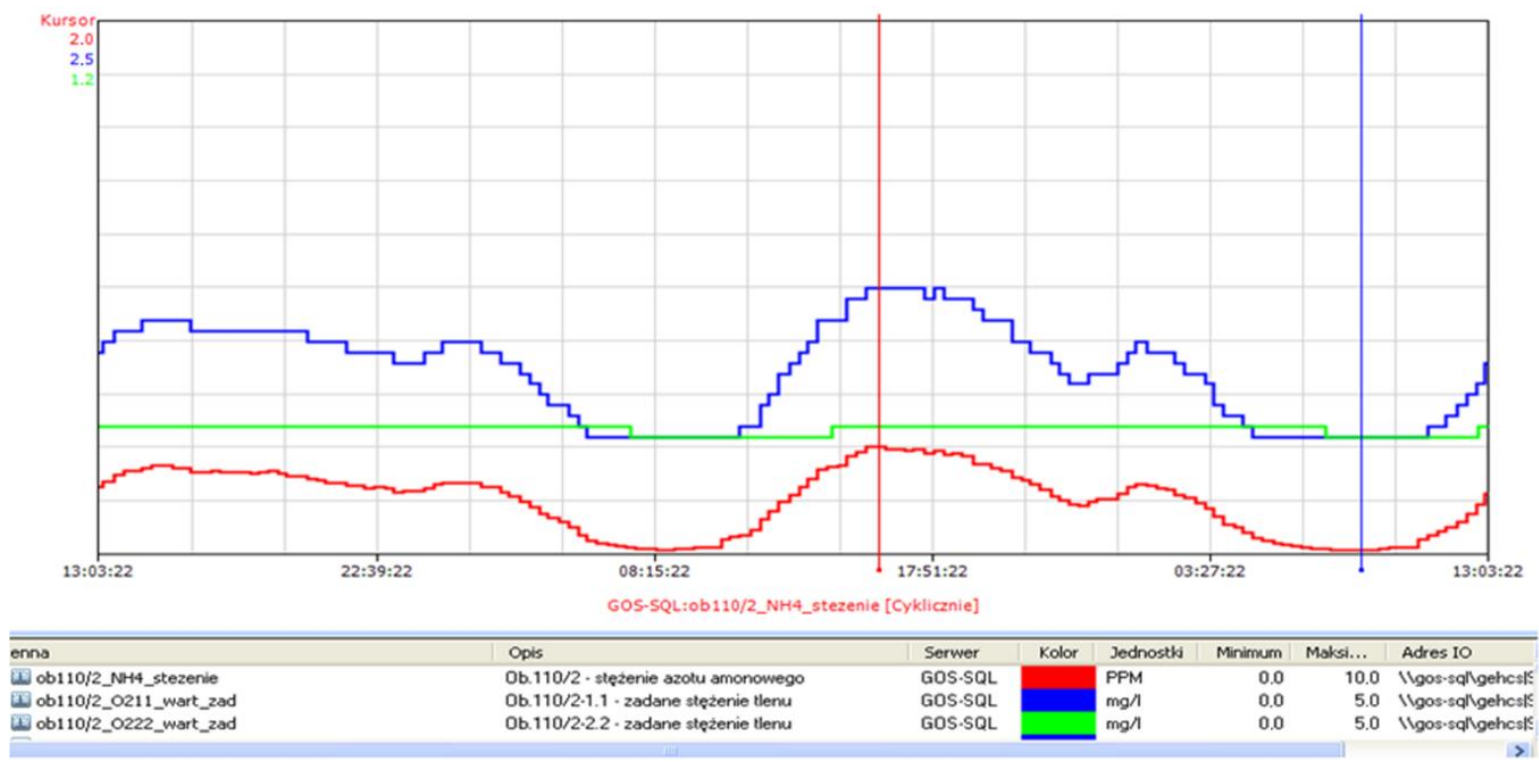

Figure 3. Aeration depending on the ammonia nitrogen concentration.

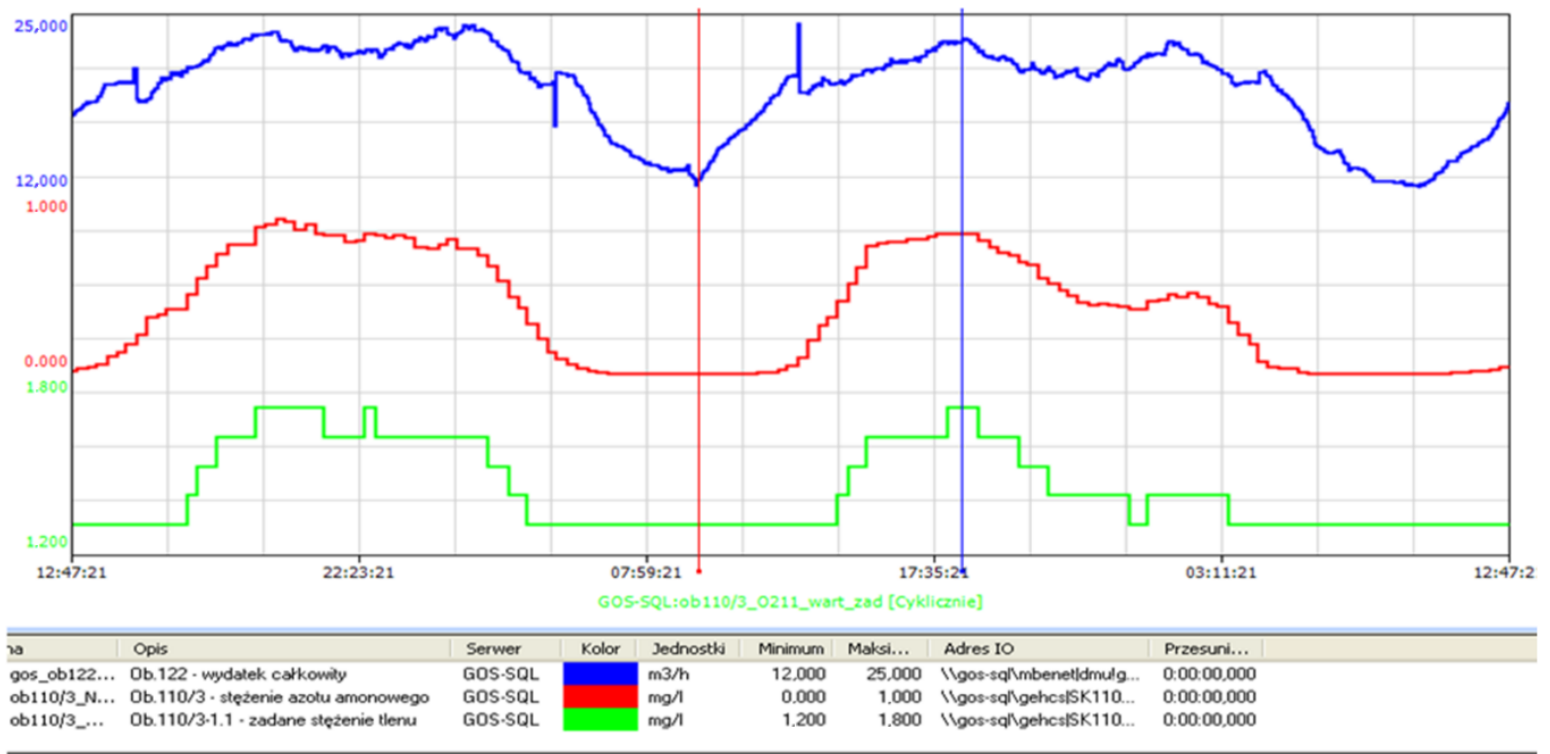

Figure 4. Variability of the set oxygen level and blower efficiency depending on the ammonia nitrogen concentration.

While considering the energy-efficiency of the applied bioreactor aeration system employing the adopted process control strategy, a 15-25\% decrease in the energy consumption was observed in comparison to the preceding year, prior to modernization. 


\section{Summary and Conclusions}

In the presented paper it was emphasized that the consumption of electricity for aeration corresponds to the largest share of the total power consumption, and the total cost of electricity for the wastewater treatment process constitutes a significant part of the plant budget. Following the European standards, Polish operators must bear in mind that implementation of optimizing solutions in order to reduce the cost of one of the most energy-demanding technological processes will bring substantial profits. Unfortunately, before the process can be optimized, the system should be equipped with suitable metering devices. Only when relevant data is available, can the improvement be carried out.

The main challenge of this study was to compare the aeration control strategies for energy process control and develop a control system. Obtained data was used also for the optimization of the biological nutrients elimination and the oxygen consumption, based on sensors e.g., DO and $\mathrm{NO}_{3} / \mathrm{NH}_{4}$ and control systems in the aeration zone of the bioreactor in the studied "Dębogórze" WWTP. Although the two controllers are different because of their different goals, they contribute to limiting complete nitrification for increased denitrification and aeration energy savings. The $\mathrm{NH}_{4}-\mathrm{N}$ and $\mathrm{NO}_{\mathrm{x}}-\mathrm{N}$ oxidation follows a typical Monod curve, which suggests a linear increase in nitrifier bacteria

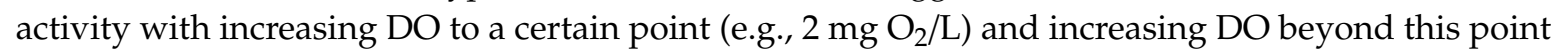
has no added benefit since the nitrification rate is kinetically limited by the nitrifier concentration. The nitrifier concentration in a system is determined by the average influent $\mathrm{NH}_{4}-\mathrm{N}$ load and could only change in a matter of days. Therefore, the $\mathrm{NH}_{4}-\mathrm{N}$ control based on increasing the aeration intensity is limited by the aerated fraction of nitrifiers in a system. However, this limitation might be alleviated by increasing the aerated volume so that more nitrifiers would be active. The use of volume control (e.g., switching swing zones) is often based on the influent $\mathrm{NH}_{4}-\mathrm{N}$ load, also known as feedforward control. Feedforward volume control could be a robust tool to provide protection against the influent peak $\mathrm{NH}_{4}-\mathrm{N}$ loads compared to feedback control which might be slower to react under such situations. Furthermore, this aeration strategy of cycling the reactor through controlled aerated and un-aerated periods based on effluent $\mathrm{NH}_{4}-\mathrm{N}$ provides the similar control authority as volume control. Therefore, volume control as well as HRT, SRT play an important role in balancing total $\mathrm{N} / \mathrm{COD}$ removal by better utilizing the plant capacity for both nitrification and denitrification, what is connected directly with operation cost. However, this flexibility and optimization is not available in the conventional systems where nitrification and denitrification volumes are fixed regardless of the influent loads and operating conditions.

The fact that the majority of Polish wastewater treatment plants are equipped with highly efficient fine-bubble diffuser systems should be considered a plus. However, it is important that the operator regularly maintains its good condition and high efficiency. As far as the energy intensity of the process is concerned, application of the simplest automatic control strategies, despite the availability of much more advanced solutions, is troubling.

Author Contributions: J.D. and A.R.-S. developed the concept of the article and wrote the outline of the paper draft; S.D. and G.Ł. analyzed information, translated, formatted and improved the paper draft. All authors of this article provided substantive comments.

Funding: This work was partly financially supported by Ministry of Science and Higher Education in Poland, within the statutory research of particular scientific units and by Shanghai international collaboration project (17230741000).

Conflicts of Interest: The authors declare no conflict of interest.

\section{References}

1. Spencer, D.; Murdoch, F. The Role of Respirometry in Maximising Aerobic Treatment Plant Efficiency; Strathkelvin Instruments Ltd.: Glasgow, UK, 2002.

2. Bodington, V.; Langford, A.; Dooley, M.; Diamond, K. Cardiff WWTW Aeration Optimisation through Scientific Control; Strathkelvin Instruments Ltd.: Glasgow, UK, 2009. 
3. Godniok, M.; Korczak, K.; Zdebik, D. Metodyczne aspekty analizy aktywności oddechowej mikroorganizmów osadu czynnego w odniesieniu do możliwości optymalizacji pracy biologicznej oczyszczalni ścieków/ Methodical aspects of analysis of respiratory activity of microorganisms in the activated sludge, in reference to the possibility of biological treatment plant work optimization. Prace Naukowe GIG 2010, 1, 5-15.

4. Quant, B.; Remiszewska-Skwarek, A.; Manini, K. Dezintegracja niskotemperaturowa jako skuteczny sposób kondycjonowania osadów ściekowych. In Polska Inżynieria Środowiska; Dudzińska, M.R., Pawłowski, A., Eds.; Komitetu Inżynierii Środowiska PAN: Lublin, Poland, 2012; Volume 99, pp. 131-146.

5. Woźniak-Vecchie, R. Biologiczne oczyszczanie ścieków. Sztuka napowietrzania. Mag. Instal. 2014, 187, $46-48$.

6. Dereszewska, A.; Cytawa, S. Zastosowanie sondy do pomiaru zawartości azotu amonowego i azotanowego jako element sterowania procesem oczyszczania ścieków/Implementation of the ammonium and nitrate sensor as an element of wastewater treatment process control. Econ. Menag. 2012, 1, 127-136.

7. Bennett, A. Wastewater treatment: Bubbling up for major energy saving. Filtr. Separat. 2011, 48, 42-43.

8. Water Environment Federation. Energy Conservation in Wastewater Treatment Facilities-Manual and Practice; No 32; WEF Press: Alexandria, VA, USA, 2009.

9. Turunen, V.; Sorvari, J.; Mikola, A. A decision support tool for selecting the optimal sewage sludge treatment. Chemosphere 2018, 193, 521-529. [CrossRef]

10. Flores-Alsina, X.; Arnell, M.; Amerlinck, Y.; Corominase, L.; Gernaey, K.V.; Guo, L.; Lindbloma, E.; Nopens, I.; Porro, J.; Shaw, A.; et al. Balancing effluent quality, economic cost and greenhouse gas emissions during the evaluation of (plant-wide) control/operational strategies in WWTPs. Sci. Total Environ. 2014, 466-467, 616-624. [CrossRef] [PubMed]

11. Mannina, G.; Cosenza, A.; Gori, R.; Garrido-Baserba, M.; Sobhani, R.; Rosso, D. Greenhouse gas emissions from wastewater treatment plants on a plantwide scale: Sensitivity and uncertainty analysis. J. Environ. Eng. 2016, 142, 04016017. [CrossRef]

12. Mannina, G.; Ekama, G.; Caniani, D.; Cosenza, A.; Esposito, G.; Gori, R.; Garrido-Baserba, M.; Rosso, D.; Olsson, G. Greenhouse gases from wastewater treatment-A review of modelling tools. Sci. Total Environ. 2016, 551-552, 254-270. [CrossRef]

13. Barbu, M.; Vilanova, R.; Meneses, M.; Santin, I. Global evaluation of wastewater treatment plants control strategies including $\mathrm{CO}_{2}$ emissions. IFAC Pap OnLine 2017, 50, 12956-12961. [CrossRef]

14. Solon, K.; Flores-Alsina, X.; Kazadi Mbamba, C.; Ikumi, D.; Volcke, E.I.P.; Vaneeckhaute, C.; Ekama, G.; Vanrolleghem, P.A.; Batstone, D.J.; Gernaey, K.V.; et al. Plantwide modelling of phosphorus transformations in wastewater treatment systems: Impacts of control an operational strategies. Water Res. 2017, 113, 97-110. [CrossRef]

15. Arnell, M.; Rahmberg, M.; Oliveira, F.; Jeppsson, U. Multiobjective performance assessment of wastewater treatment plants combining plant-wide process models and life cycle assessment. J. Water Clim. Chang. 2017, 8, 715-729. [CrossRef]

16. Zaborowska, E.; Czerwionka, K.; Makinia, J. Strategies for achieving energy neutrality in biological nutrient removal systems-A case study of the Slupsk WWTP (northern Poland). Water Sci. Technol. 2017, 75, 727-740. [CrossRef] [PubMed]

17. Dominguez, D.; Gujer, W. Evolution of a wastewater treatment plant challenges traditional design concepts. Water Res. 2006, 40, 1389-1396. [CrossRef] [PubMed]

18. Drewnowski, J.; Remiszewska-Skwarek, A.; Fernandez-Morales, F.J. Model based evaluation of plant improvement at a large wastewater treatment plant (WWTP). J. Environ. Sci. Health A 2018, 53, 1-7. [CrossRef]

19. Drewnowski, J.; Remiszewska-Skwarek, A.; Fudala-Ksiazek, S.; Luczkiewicz, A.; Kumari, S.; Bux, F. The evaluation of COD fractionation and modeling as a key factor for appropriate optimization and monitoring of modern cost-effective activated sludge systems. J. Environ. Sci. Health A 2019, 54, 1-7. [CrossRef] [PubMed]

20. Heidrich, Z.; Witkowski, A. Wybór systemu napowietrzania w procesie oczyszczania ścieków metoda osadu czynnego. Inż. Ekol. 2006, 14, 12-15.

21. Łomotowski, J.; Szpindor, A. Nowoczesne Systemy Oczyszczania Ścieków; Arkady: Warszawa, Poland, 1999.

22. Bever, J.; Stein, A.; Teichmann, H. Zaawansowane Metody Oczyszczania Ścieków; Oficyna Wydawnicza Projprzem-Eko: Bydgoszcz, Poland, 1997. 
23. Longo, S.; Mirko, B.A.; Bongards, M.; Chaparro, A.; Cronrath, A.; Fatone, F.; Lema, J.M.; Mauricio-Iglesias, M.; Soares, A.; Hospido, A. Monitoring and diagnosis of energy consumption in wastewater treatment plants. A state of the art and proposals for improvement. Appl. Energy 2016, 179, 1251-1268. [CrossRef]

24. Guerrini, A.; Romano, G.; Indipendenza, A. Energy Efficiency Drivers in Wastewater Treatment Plants: A Double Bootstrap DEA Analysis. Sustainability 2017, 9, 1126. [CrossRef]

25. Janiak, K. Stopień wykorzystania tlenu i czynniki na niego wpływające: Część I/ Oxygen transfer efficiency and its influencing factors: Part 1. Forum Eksploatatora 2012, 4, 44-49.

26. German, A.T.V. Rules and Standards. In ATV M 209E, Measurement of the Oxygen Transfer Inactivated Sludge Aeration Tanks with Clean Water and in Mixed Liquor; Gesellschaft zur Förderung der Abwassertechnik e.V. (GFA): Hennef, Germany, 1996.

27. Chern, J.M.; Chou, S.R.; Shang, C.S. Effects of impurities on oxygen transfer rates in diffused aeration system. Water Res. 2001, 35, 3041-3048. [CrossRef]

28. US EPA. Development of Standard Procedures for Evaluating Oxygen Transfer Devices; EPA-600/2-83-102; EPA: Washington, DC, USA, 1983.

29. Stenstrom, M.K.; Gilbert, R.G. Effects of $\alpha, \beta$ and $\theta$ factor upon the design, specification and operation of aeration systems. Water Res. 1981, 15, 643-654. [CrossRef]

30. Downing, A.L.; Bayley, R.W.; Boon, A.G. The performance of mechanical aerators. J. Inst. Sewage Purif. 1960, 3, 231-242.

31. Eckenfelder, W.W.; Raymond, L.W.; Lauria, D.T. Effect of various organic substances on oxygen absorption efficiency. Sewage Ind. Wastes 1956, 28, 1357-1364.

32. Fisher, M.J.; Boyle, W.C. Effect of anaerobic anoxic selectors on oxygen transfer in wastewater. Wat. Environ. Res. 1999, 71, 84-93. [CrossRef]

33. Hwang, H.J.; Stenstrom, M.K. The Effect of Surface Active Agent on Oxygen Transfer; UCLA-ENG-79-30; University of California: Los Angeles, CA, USA, 1979.

34. Krampe, J.; Krauth, K. Oxygen transfer into activated sludge with high MLSS concentrations. Water Sci. Technol. 2003, 47, 297-303. [CrossRef] [PubMed]

35. Rosso, D.; Larson, L.E.; Stenstrom, M.K. Aeration of large-scale municipal wastewater treatment plants state of the art. Water Sci. Technol. 2008, 57, 973-978. [CrossRef]

36. Mueller, J.A.; Boyle, W.C.; Pöpel, H.J. Aeration: Principles and Practice; CRC Press: Boca Raton, FL, USA, 2002.

37. Wagner, M.; Krause, S. Investigation of oxygen transfer rates in full scale membrane bioreactors. Water Sci. Technol. 2003, 47, 313-319. [CrossRef]

38. Fröse, G. Praxiserfahrungen mit dem ATV-Merkblatt M 209 und Vorstellung des neuen europäischen Norm-Entwurfes DIN EN 12255-15 zur Messung der Sauerstoffzufuhr in Reinwasser. Schriftenreihe WAR 2001, 134, 57-70.

39. Piotrowski, R. Wielopoziomowy system sterowania stężeniem tlenu I wyznaczania trajektorii zadanej stężenia tlenu w biologicznej oczyszczalni ścieków/Multilevel control system for dissolved oxygen control and determining the set point trajectory of dissolved oxygen in a biological watewater treatment plant. Pomiary Automatyka Robotyka 2018, 4, 19-23. [CrossRef]

40. US EPA. Fine Pore Aeration Systems-Design Manual; EPA/625/1-89/023; EPA: Washington, DC, USA, 1989.

41. Hung, C.H.; Boyle, W.C. The effect of acid cleaning on a fine pore ceramic diffuser aeration, system. Water Sci. Technol. 2001, 44, 211-218. [CrossRef] [PubMed]

42. Szetela, R.; Janiak, K.; Balbierz, P.; Knap, M. Optymalizacja pracy systemu napowietrzania bloków biologicznych pod katem minimalizacji kosztów napowietrzania Wrocławskiej Oczyszczalni Ścieków cz. 3, Raport serii SPR nr 7/2012; Instytut Inżynierii Ochrony Środowiska, Politechnika Wrocławska: Wrocław, Poland, 2012.

43. Janiak, K. Stopień wykorzystania tlenu i czynniki na niego wpływające: Część II Zarastanie dyfuzorów/ Oxygen transfer efficiency and its influencing factors Part 2: Diffuser's fouling. Forum Eksploatatora 2012, 5, 30-36.

44. Frey, W.; Thonhauser, C. Clogging and cleaning of fine-pore membrane diffusers. Water Sci. Technol. 2004, 50, 69-77. [CrossRef]

45. Hansen, E.J.; Estevez, M.A.; Es-Said, O.S. On the shrinking and hardening of EPDM rubber membranes in water sanitation filtration tanks. Eng. Fail. Anal. 2004, 11, 361-367. [CrossRef]

46. Wagner, M.; Hoessle, V.R. Biological coating of EPDM-membranes of fine bubble diffusers. Water Sci. Technol. 2004, 50, 79-85. [CrossRef] [PubMed] 
47. Libra, J.A.; Sahlmann, C.; Schuchardt, A.; Handschag, J.; Wiesmann, U.; Gnirss, R. Evaluation of ceramic and membrane diffusers under operating conditions with the dynamic of gas method. Water Environ. Res. 2005, 77, 447-454. [CrossRef]

48. Szetela, R.; Janiak, K.; Balbierz, P.; Knap, M. Ekspertyza techniczna—Badania laboratoryjne stopnia wykorzystania tlenu oraz strat ciśnienia dyfuzorów wymontowanych z nowo wybudowanych reaktorów tlenowych Wroctawskiej Oczyszczalni Ścieków; Instytut Inżynierii Ochrony Środowiska, Politechnika Wrocławska: Wrocław, Poland, 2011.

49. Thomas, C.D.; Barratt, P.A.; Holmes, R.B. Systemy Oxy-Dep Vsa, Nowe rewolucyjne podejście do kwestii napowietrzania w procesie oczyszczania ścieków. Inży. Ekol. 2006, 14, 17-29.

50. EPA 832-F-99-065 Wastewater Technology Fact Sheet-Fine Bubble Aeration; EPA: Washington, DC, USA, 1999.

51. Ovezea, A. Saving energy: Using fine bubble diffusers. Filtr. Sep. 2009, 46, 24-27. [CrossRef]

52. Roman, M.D.; Muresan, M.V. Analysis of oxygen requirements and transfer efficiency in a wastewater treatment plant. Int. J. Latest Res. Sci. Technol. 2014, 3, 30-33.

53. Garrido-Baserba, M.; Asvapathanagul, P.; McCarthy, G.W.; Gocke, T.E.; Olson, B.H.; Park, H.; Al-Omari, A.; Murthy, S.; Bott, C.B.; Wett, B.; et al. Linking biofilm growth to fouling and aeration performance of fine-pore diffuser in activated sludge. Water Res. 2016, 90, 317-328. [CrossRef]

54. Garrido-Baserba, M.; Sobhani, R.; Asvapathanagul, P.; McCarthy, G.W.; Gocke, T.E.; Olson, B.H.; Odize, V.; Al-Omari, A.; Murthy, S.; Nifong, A.; et al. Modelling the link amongst fine-pore diffuser fouling, oxygen transfer efficiency, and aeration energy intensity. Water Res. 2017, 111, 127-139. [CrossRef]

55. Sadecka, Z.; Płuciennik-Koropczuk, E.; Sieciechowicz, A. Modele biokinetyczne ASM/Biokinetic models ASM. Zeszyty Naukowe. Inżynieria Środowiska Uniwersytet Zielonogórski 2011, 141, 113-125.

56. Henze, M.; Gujer, W.; Mino, T.; Loosdrecht, M. Activated Sludge Models ASM1, ASM2, ASM2D and ASM3; Edited by IWA Task Group on Mathematical Modelling for Design and Operation of Biological Wastewater Treatment; IWA Publishing: London, UK, 2000.

57. Olsson, G.; Newell, B. Wastewater Treatment Systems. Modeling, Diagnosis and Control; IWA Publishing: London, UK, 1999.

58. Szetela, R. Model Dynamiczny Oczyszczalni ścieków z Osadem Czynnym; Prace Naukowe Instytutu Ochrony Środowiska Politechniki Wrocławskiej, 64, Monografie 32; Wydawnictwo Politechniki Wrocławskiej: Wrocław, Poland, 1990.

59. Urban, R.; Szetela, R. Calibration of the activated sludge model with genetic algorithms. Part i. Calibration results. Environ. Prot. Eng. 2007, 33, 31-49.

60. Cawley, G.; Janarek, G.; Haylock, M.; Dorling, S. Predictive uncertainty in environmental modelling. Neural Netw. 2007, 20, 537-549. [CrossRef] [PubMed]

61. Bsdys, M.A.; Díaz Maíquez, J. Application of Fuzzy Model Predictive Control to the Dissolved Oxygen Concentration Tracking in an Activated Sludge Process. In Proceedings of the 15th IFAC World Congress, Barcelona, Spain, 21-26 July 2002.

62. Szetela, R.; Dymaczewski, Z. Modyfikacja obecnej postaci modelu osadu czynnego ASM 2d/ Modification of the present form of the ASM 2d acivated sludge model. Ochr. Środ. 2002, 1, 3-8.

63. Gujer, W.; Henze, M.; Mino, T.; Matsuo, T.; Wentzel, M.C.; Marais, G.V.R. The Activated Sludge Model. Water Sci. Technol. 1995, 31, 1-11. [CrossRef]

64. Henze, M.; Gujer, W.; Mino, T.; Matsuo, T.; Wentzel, M.C.; Marais, G.V.R.; Van Loosdrecht, C.M. Activated sludge model No.2D, ASM2D. Water Sci. Technol. 1999, 39, 165-182. [CrossRef]

65. Winkler, S.; Müller-Rechberger, H.; Nowak, O.; Svardal, K.; Wandl, G. A New approach towards model ling of the carbon degradation cycle AT two-stage activated sludge plants. Water Sci. Technol. 2001, 43, 19-27. [CrossRef] [PubMed]

66. Rieger, L.; Koch, G.; Kühni, M.; Gujer, W.; Siegrist, H. The EWAG BIO-P module for Activated Sludge Model No. 3. Water Res. 2001, 35, 3887-3903. [CrossRef]

67. Jones, G.L. A mathematical model for bacterial growth and substrate utilisation in the activated-sludge process. In Mathematical Models in Water Pollution Control; James, A., Ed.; John Wiley and Sons: London, UK, 1978; pp. 265-279.

68. Chambers, B.; Jones, G.L. Optimisation and Uprating of Activated Sludge Plants by Efficient Process Design. Water Sci. Technol. 1988, 20, 121-132. [CrossRef]

69. Murnleitner, E.; Kuba, T.; Van Loosdrecht, M.C.M.; Heijnen, J.J. An integrated metabolic model for the aerobic and denitrifying biological phosphorus removal. Biotechnol. Bioeng. 1997, 54, 434-450. [CrossRef] 
70. Van Veldhuizen, H.M.; Van Loosdrecht, M.C.M.; Heijnen, J.J. Modelling biological phosphorus and nitro gen removal in a full scale activated sludge process. Water Res. 1999, 33, 3459-3468. [CrossRef]

71. Szabat, K.; Urban, R. Zastosowanie logiki rozmytej do sterowania napedowymi układami napowietrzania komór tlenowych w oczyszczalni ścieków/Application of the fuzzy logic to control the electrical blowers in the sewage treatment plant. Prace Naukowe IMNiPE Politechniki Wrocławskiej 2009, 63, 341-354.

72. Kalker, T.J.J.; Van Goor, C.P.; Roeleveld, P.; Ruland, M.F. Fuzzy Control of Aeration in an Activated Sludge Wastewater Treatment Plant: Design, Simulation and Evaluation. Water Sci. Technol. 1999, 4, 71-78. [CrossRef]

73. Stare, A.; Vrecko, D.; Hvala, N.; Strmcnik, S. Comparison of control strategies for nitrogen removal in an activated sludge process in terms of operating costs: Simulation study. Water Res. 2007, 41, 2004-2014. [CrossRef] [PubMed]

74. Borowa, A.; Brdyś, M.; Mazur, K. Modeling of wastewater treatment plant for monitoring and control purposes by state-space wavelet networks. IJCCC 2007, 2, 121-131. [CrossRef]

75. Amand, L.; Carlsson, B. Aeration Control with Gain Scheduling in a Full-scale Wastewater Treatment Plant. IFAC Proc. Vol. 2014, 47, 7146-7151. [CrossRef]

76. Regmi, P.; Miller, M.W.; Holgate, B.; Bunce, R.; Park, H.; Chandran, K.; Wett, B.; Murthy, S.; Bott, C.B. Control of aeration, aerobic SRT and COD input for mainstream nitritation/denitritation. Water Res. 2014, 57, 162-171. [CrossRef] [PubMed]

77. Kaelin, D.; Manser, R.; Rieger, L.; Eugster, J.; Rottermann, K.; Siegrist, H. Extension of ASM3 for two-step nitrification and denitrification and its calibration and validation with batch tests and pilot scale data. Water Res. 2009, 43, 1680-1692. [CrossRef] [PubMed]

78. Zaborowska, E.; Majtacz, J.; Drewnowski, J.; Sobotka, D.; Al-Hazmi, H.; Kowal, P.; Mąkinia, J. Improving the energy balance in wastewater treatment plants by optimization of aeration control and application of new technologies. In Water Supply and Wastewater Disposal; Sobczuk, H., Kowalska, B., Eds.; LUT: Lublin, Poland, 2018; pp. 317-328.

79. Maktabifard, M.; Zaborowska, E.; Makinia, J. Achieving energy neutrality in wastewater treatment plants through energy savings and enhancing renewable energy production. Rev. Environ. Sci. Biotechnol. 2018, 17, 655-689. [CrossRef]

80. U.S. Municipal Solid Waste Sector Action Plan. 2013. Available online: https://www.globalmethane.org/ documents/landfills_cap_usa.pdf. (accessed on 5 May 2019).

81. Piao, W.; Kim, Y.; Kim, H.; Kim, M.; Kim, C. Life cycle assessment and economic efficiency analysis of integrated management of wastewater treatment plants. J. Clean. Prod. 2016, 113, 325-337. [CrossRef]

82. Guerrini, A.; Romano, G.; Leardini, C. Economic of scale and density in the Italian water industry: A stochastic frontier approach. Util. Policy 2018, 52, 103-111. [CrossRef]

83. Daelman, M.R.J.; Van Voorthuizen, E.M.; Van Dongen, L.G.J.M.; Volcke, E.I.P.; van Loosdrecht, M.C.M. Methane and nitrous oxide emissions from municipal wastewater treatment-Results from a long-term study. Water Sci. Technol. 2013, 67, 2350-2355. [CrossRef] [PubMed]

84. Remy, C.; Lesjean, B.; Waschnewski, J. Identifying energy and carbon footprint optimization potentials of a sludge treatment line with life cycle assessment. Water Sci. Technol. 2013, 67, 63-73. [CrossRef] [PubMed]

85. De Haas, D.W.; Pepperell, C.; Foley, J. Perspectives on greenhouse gas emission estimates based on Australian wastewater treatment plant operating data. Water Sci. Technol. 2014, 69, 451-463. [CrossRef]

86. Mamais, D.; Noutsopoulos, C.; Dimopoulou, A.; Stasinakis, A.; Lekkas, T.D. Wastewater treatment process impact on energy savings and greenhouse gas emissions. Water Sci. Technol. 2015, 71, 303-308. [CrossRef] [PubMed]

87. Bao, Z.; Sun, S.; Sun, D. Assessment of greenhouse gas emission from A/O and SBR wastewater treatment plants in Beijing, China. Int. Biodeterior. Biodegrad. 2016, 108, 108-114. [CrossRef]

88. Wang, H.; Yang, Y.; Keller, A.A.; Li, X.; Feng, S.; Dong, Y.; Li, F. Comparative analysis of energy intensity and carbon emissions in wastewater treatment in USA, Germany, China and South Africa. Appl. Energy 2016, 184, 873-881. [CrossRef]

89. Evangelisti, S.; Lettieri, P.; Borello, D.; Clift, R. Life cycle assessment of energy from waste via anaerobic digestion: A UK case study. Waste Manag. 2014, 34, 226-237. [CrossRef] 
90. Arashiro, L.T.; Montero, N.; Ferrer, I.; Acién, F.G.; Gómez, C.; Garfí, M. Life cycle assessment of high rate algal ponds for wastewater treatment and resource recovery. Sci. Total Environ. 2018, 622-623, 1118-1130. [CrossRef]

91. Polruang, S.; Sirivithayapakorn, S.; Prateep Na Talang, R. A comparative life cycle assessment of municipal wastewater treatment plants in Thailand under variable power schemes and effluent management programs. J. Clean. Prod. 2018, 172, 635-648. [CrossRef]

92. Herna'ndez-Sancho, F.; Molinos-Senante, M.; Sala-Garrido, R. Energy efficiency in Spanish wastewater treatment plants: A non-radial DEA approach. Sci. Total Environ. 2011, 409, 2693-2699. [CrossRef] [PubMed]

93. Sala-Garrido, R.; Herna'ndez-Sancho, F.; Molinos-Senante, M. Assessing the efficiency of wastewater treatment plants in an uncertain context: A DEA with tolerances approach. Environ. Sci. Policy 2012, 18, 34-44. [CrossRef]

94. Molinos-Senante, M.; Hernández-Sancho, F.; Mocholí-Arce, M.; Sala-Garrido, R. Economic and environmental performance of wastewater treatment plants: Potential reductions in greenhouse gases emissions. Resour. Energy Econ. 2014, 38, 125-140. [CrossRef]

95. Lorenzo-Toja, Y.; Alfonsin, C.; Amores, M.J.; Aldea, X.; Marin, D.; Moreira, M.T.; Feijoo, G. Beyond the conventional life cycle inventory in wastewater treatment plants. Sci. Total Environ. 2016, 553, 71-82. [CrossRef] [PubMed]

96. Hydromantis ESS, Inc. GPS-X Technical Reference; Hydromantis ESS, Inc.: Hamilton, ON, Canada, 2017.

97. Nelder, J.A.; Mead, R. A simplex method for function minimization. Comput. J. 1965, 7, 308-313. [CrossRef]

(C) 2019 by the authors. Licensee MDPI, Basel, Switzerland. This article is an open access article distributed under the terms and conditions of the Creative Commons Attribution (CC BY) license (http://creativecommons.org/licenses/by/4.0/). 